\title{
Higher Education Regionalization in the Northern Triangle of Central America: Guatemala, El Salvador and Honduras
}

\author{
Jermain Griffin* and Lisbeth R. Gall \\ American University, United States \\ *Corresponding author: Email: jermaing@american.edu \\ Address: American University, Washington, D.C., United States
}

\section{Introduction}

The ongoing migrant crisis that engulfs the U.S.-Mexico border is often the source of political and socioeconomic discourse related to the treatment of those caught in the web of immigration politics or the causes of migration to the U.S. from Mexico and Central America. One related, critical conversation involves the future stability of countries neighboring the southern region of Mexico - El Salvador, Guatemala, and Honduras. Together they comprise the northern region of Central America, increasingly referred to as the Northern Triangle (NT). The region is documented for its lower levels of human development, high rates of violent crime, low school completion rates and high rates of poverty (Meyer and Seelke 2015; Congressional Research Service 2019). The U.S. government has maintained regular engagement with NT countries to support the development of greater stabilization in the region following decades of internal armed conflicts and the aftermath, which contributed to lower human development in the region. In recent years, the United States Agency for International Development (USAID) has supported efforts towards public health, business development, efficient government institutions and the scaling up of postsecondary education through grants with regional and international partners. In 2014, the Plan of the Alliance for the Prosperity of the Northern Triangle (A4P) was developed by the leaders of El Salvador, Guatemala, and Honduras, in partnership with the U.S. to improve overall living conditions through coordination efforts focused on areas of need including access to basic healthcare, nutrition, education and employment opportunities (Inter-American Development Bank 2014). While the Plan of the Alliance does not explicitly reference the role of higher education (HE), we argue that it is reasonable and important to question how and if higher education institutions (HEIs) from the NT can contribute to improving social and economic conditions in the region. One important question about $\mathrm{HE}$ in the region is the level of collaboration between HEIs within the region that exists and how much of it is dependent on external support compared to available resources within the NT. This paper examines existing HE partnerships through a theoretical lens of higher education regionalization led by Knight's (2013) framework for regionalization. It is important to understand the capacity of HEIs in the region to facilitate collaboration. This paper begins to answer that question by exploring the depth of collaboration between HEIs in the NT region. How many partnerships are there and what are the context of those partnerships? This paper offers an important overview of the current state of HE collaboration in the region and how future collaborations might be fostered.

\section{The Northern Triangle}

Among Central American countries, Costa Rica and Panama have shown a steady economic growth and have maintained the highest gross domestic product (GDP) (Casalet and Buenrostro 2014). Their annual GDP per capita surpasses $\$ 7,000$, therefore categorized as upper middle-income countries, whereas the Northern Triangle (NT) maintains an average between $\$ 2,000$ and $\$ 3,000$ (Svenson 2013). In terms of development, NT countries are 
regularly categorized has having medium human development (UNDP 2019). The United Nations Development Program (UNDP) Human Development Index (HDI) draws from key 2030 UN Sustainable Development goals such as good health and well-being, quality education and economic mobility (United Nations 2019).

Regarding the political and economic stability, Colburn and Cruz (2016) state that "democracy in these three countries is weak, marred by political fragmentation, party instability, corruption, and feeble state capacity" (80). Despite the expansion of higher education (HE) in Central America, the World Bank (Ferreyra et al. 2017) study on HE in Latin America and the Caribbean (LAC) found high levels of unequal access to education in NT countries. This has resulted in limited development opportunities for citizens that translates into violence, poverty and increased emigration patterns. The shared social and economic issues in this region led the leaders in NT countries to form a strategic alliance aimed at addressing the problems threatening the security and development of their region.

\section{The Northern Triangle Prosperity Alliance}

The NT region's persistent struggles with violent crime and poverty reduction further exacerbated the flow of migrants north to Mexico, then onward to the U.S. These trends prompted the development of the Plan of the Alliance for the Prosperity of the Northern Triangle or A4P. The Plan was an attempt by NT countries, with support from the U.S., to invest in creating the conditions for increased economic development, job opportunities, improved public safety and strong public institutions leading each country (Inter-American Development Bank 2014). During the 201617 period, the three NT countries committed a combined \$5.4 billion towards successful implementation of the A4P (U.S. Department of State 2018). The Plan's emphasis on improving secondary education completion rates and investing in workforce development represents opportunities for the region's higher education sector to contribute the Plan's implementation.

We contend that higher education should be examined for its potential to contribute in the NT context. The A4P continues to represent a key opportunity to improve the NT region through strategic partnership and coordination. In order to understand if and how higher education might serve a critical role in fostering mutually beneficial partnership that increases quality of life in the region, it is important to first understand the current state of higher education partnership activity between institutions in the region.

\section{Literature Review}

In recent years, research has emphasized the complexity but importance of higher education collaborations, be they international, regional or transborder. While there is no linear frame of reference for terms such as 'collaboration' or 'partnership' in the higher education context, there is sensitivity to the variability of these linkages. They can range from individual scholar collaborations to system-level coordinated efforts to support the building up of higher education systems with limited resources. In North-South higher education partnerships, respect for contextual factors and careful handling of power dynamics (particularly for well-resourced northern institutions) to ensure a reasonable level of mutuality of benefits are found in such alliances (Koehn 2012; Irazabal et. al 2015).

\section{Higher Education Collaboration Efforts in Central America}

Svenson's (2018) case study of the Central American Institute of Business Administration (INCAE) examines a North-South research collaboration between INCAE institutions (largely from Costa Rica and Nicaragua) and Harvard University. The case highlighted interpersonal dynamics as foundational to such international collaborations, which can eventually lead to broader organizational collaborations (Svenson 2018). The conditions for higher education linkages in Central America date back several decades. 
In 1948 the Central American University Confederation and the Central American University Council of Universities (Consejo Superior Universitario Centroamericano, CSUCA) was established to foster higher education coordination among universities in the region (CSUCA, 2019). The council's membership is comprised of the state universities of Belize, Guatemala, El Salvador, Honduras, Nicaragua, Costa Rica, Panamá, and Dominican Republic (CSUCA 2019). The contributions of CSUCA include the creation of structures and systems to improve the delivery of higher education services (Swallow 1975; Soto and Sáurez 2014; CSUCA 2019). The harmonization process has been slow, in part because of the economic and structural differences among the region's countries. Casalet and Buenrostro (2014) explain that in cooperation processes, difference among countries may weaken cooperation efforts.

Other key regional contributors to ongoing efforts to strengthen higher education connectivity include the Association of Private Universities in Central America (AUPRICA), founded in 1990 and the Central American Agency of Graduate Accreditation (ACAP). Both organizations are part of a regional effort to build integration of teaching, research and in some cases, organizational leadership, to benefit public and private HEIs in Central America (ACAP, 2019; AUPRICA 2019). A key regional actor for the discussion in this paper is the Central American Integration System (Sistema de Integracion de Centroamerica, SICA). Established in 1991 and recognized by the United Nations, SICA is an economic, political and social alliance between the seven Central American countries and the Dominican Republic. The regional alliance uses a variety of outlets including academic centers to promote regional integration (Carducci \& Amaya, 2012; SICA, 2019). These examples of regional integration efforts draw from existing models of regionalization, which will be discussed in the next section.

\section{Higher Education Regionalization}

Knight (2013) describes higher education regionalization as a "process of intentionally building connections and relationships among higher education actors, structure and systems within a region" (113). Regionalization attributes a proactive role and agency to higher education. This process can lead regions to improve higher education institutions (HEIs) recognition as they strengthen their capacity. Furthermore, these initiatives can support and shape structural gaps among nations, reduce disparities and enhance capacities in different educational areas (Casalet and Buenrostro 2014).

The concept of regionalization of higher education is influenced by the European Union's Bologna Process (BP), which began in 1999 with the goal of building a European Higher Education Area (EHEA) by 2010. Now a 48country higher education, EHEA members implement several aspects of the BP including the streamlining degree requirements and quality assurances to support a broad network of higher education (Azevedo 2014). The EHEA has provided a model for other regional blocs to use towards aspirations of greater integration between the regions' HEIs. In the African continent, a few examples of higher education areas under development would be in the East African Community (EAC) and in the Central African Economic and Monetary Community (CEMAC) (Eta 2015; Eta, Kallo and Rinne 2018). In Asia, key higher education alliances include the Southeast Asian Ministers of Education Organization (SEAMEO) and the Association of Southeast Asian Nations Universities Network (AUN) (Chao 2014; Choi 2017).

The European model has also influenced higher education collaboration in Latin America. In 2000, the European Union-Latin America/Caribbean Higher Education Area (UEALC) was launched to build cooperation between HEIs in Europe and Latin America as well as help create greater linkages between HEIs in Latin America. While forming its regional education group in the early 1990s, before the Bologna Process, the Latin American Southern Cone Group (MERCOSUR) is found to not be as advanced in higher education regionalization compared with the EHEA. Comparative studies highlighted unique challenges that impede higher education regionalization between MERCOSUR countries including insufficient resources, variation in governance systems, cultural dynamics within 
some MERCOSUR countries that see European approaches to higher education as intrusive among other challenges (Verger and Hermo, 2010; Azevedo 2014; Felsen 2016).

A key initiative to support education regionalization in MERCOSUR and Latin American/Caribbean regional communities was the ALFA Tuning Latin America Project. The project, launched 2004, aimed to improve cooperation between universities in the region through an emphasis on a variety academic disciplines to build competences for teaching and learning. The project concluded in 2013 with nearly 20 countries, including El Salvador, Guatemala and Honduras, contributing to dialogue on building shared competences in 12 subject areas including Business, History and Medicine (Albo 2017; Tuning Academy 2019).

The Tuning Latin America Project is part of an international network of programs designed to increase higher education coordination through shared principles towards curriculum and teaching. The Tuning Academy (2019) has similar projects in both Asia and Africa, drawing on expertise from those regions as well as Europe and North America. Jane Knight (2013) offers a key contribution to the discussion of higher education regionalization in the inaugural issue of the Tuning Journal for Higher Education.

\section{Theoretical Framework}

Knight (2013) explains that the higher education regionalization process involves a variety of terms with different meanings that are often used interchangeably and are necessary to understand, such as: collaboration, harmonization, integration, among others. Knight (2013) uses these terms to develop a continuum of higher education regionalization that ranges from cooperation to integration. Regionalization is argued to begin with cooperation or collaboration with bilateral or multilateral activities between HEIs, then grow to coordination or alignment with partnerships between systems and structures. Knight (2013) suggests the following stage would involve harmonization and convergence with regional quality assurance plans or a shared academic credit system. Finally, the level of integration is where the aforementioned activities are part of a formalized higher education area. In Table 1 (below), Knight's suggested continuum is illustrated with examples of practical actions for each suggested stage.

Table 1: Knight's (2013) Continuum of Higher Education Regionalization Terms and Practical Examples

\begin{tabular}{|l|l|}
\hline Higher Education Regionalization Terms & Practical Examples \\
\hline Cooperation, Collaboration, Partnership & $\begin{array}{l}\text { Open, informal relationships } \\
\text { Faculty-led programs }\end{array}$ \\
\hline Coordination, Coherence, Alignment & $\begin{array}{l}\text { Joint-degree programs } \\
\text { System-level partnerships }\end{array}$ \\
\hline Convergence, Harmonization & $\begin{array}{l}\text { Shared academic credit system } \\
\text { Compatible quality assurance plans }\end{array}$ \\
\hline Integration, Community, Interdependence & $\begin{array}{l}\text { Agreements and bodies that legitimize plans for regional } \\
\text { higher education area }\end{array}$ \\
\hline
\end{tabular}

Source: Adopted from Knight (2013), p. 6

While higher education regionalization is a voluntary and intentional process, Knight suggests that a planned method can support the development of more strategic and sustainable relationships. For this end, Knight proposes a Functional, Organizational and Political Approaches (FOPA) model to support the regionalization process.

Knight's proposed framework for higher education regionalization - the Functional, Organizational and Political Approaches (FOPA) Model, consists of three interrelated approaches, illustrated in Table 2, that complement one another. The functional approach refers to the strategies to align a) higher education systems, and b) collaborative 
academic programs. This approach offers an analysis to further align academic systems and policies that include student mobility, quality assurance, and academic credit. The organizational approach involves the existing networks and government agencies through various levels of collaboration in order to promote initiatives, funding, capacity building, among other initiatives. The political approach "involves the political will and strategies that put higher education initiatives on the agenda of decision-making bodies" (120). Political instruments include: agreements, treaties, conventions and summits and among other events of this nature. The FOPA model helps stimulate regionalization efforts through a systematic and sustainable process.

Table 2: FOPA Approaches and Characteristics

\begin{tabular}{|l|l|}
\hline Approach & Characteristics \\
\hline Functional & Alignment of systems and policies \\
Organizational & Collaborative Programs \\
Political & Organizations \\
& Networks \\
\hline
\end{tabular}

Source: Adopted from Knight (2013), p. 7

Knight's (2013) FOPA model does not denote linearity, but interdependency, complementarity and flexibility. Knight emphasizes that the levels of collaboration and approaches used in each region are defined by higher education institutions and systems. The existing literature of higher education regional coordination in Latin America largely emphasizes efforts in from regional communities South America (MERCOSUR and the Andean Community: Colombia, Peru, Ecuador and Bolivia). Higher education research on the Central America region is still relatively obscure with the emphasis typically on activities in Mexico, Costa Rica, Panama or Nicaragua. Central America's Northern Triangle (NT) region is certainly part of regional networks to encourage higher education coordination and the harmonizing of credit policies and systems, but the field needs more research on the capacity of HEIs within the region to support regionalization.

This case study is designed to examine the capacity of HEIs in regions confronted with a myriad of social, economic and political challenges to support collaboration. Important questions for this study are: How much of existing HEI collaboration in the region is driven by institutions within the region as opposed to neighboring Central America countries or outside supporters such as the European Union and the US? What are the priorities for collaboration among NT institutions? We hypothesize that HEI collaborations for NT countries are likely to be predominantly driven by outside efforts due to weak regional systems and ongoing political, economic and social challenges.

\section{Methodology}

A case study approach was used to answer this paper's research questions. Therefore, the findings in this study are limited to this specific case, however, some aspects of the study may be helpful in making sense of regionalization cases in other context. This study has a sample of 47 HEIs (El Salvador - 24; Guatemala - 15; Honduras - 8). Kim and Kuljis' (2010) approach to content analysis of Web-based content was helpful for the study as publicly available information including downloadable documents from more than 70 Web sites were gathered and analyzed for patterns of regionalization activity. The authors cautioned that Web site data would be aided by some form of triangulation, e.g., Participant interviews. Due to economic constraints, interview data was not funded for this study. Additionally, we 
decided to incorporate perspectives of key actors from the region with perspective on HE regionalization for a future study.

The qualitative data were put through one round of coding before categories and themes were developed (Saldaña, 2013). Knight's (2013) FOPA model was used to finalize categories and interpret the findings. Three categories were created to describe partnership activities: Collaborative activities exclusively between HEIs within the NT region, which we labeled NTCLAB (Northern Triangle Collaborations); activities that included at least one NT institution and institutional partners from other Central American countries, NTCAM (Northern Triangle + Central America, Dominican Republic and Mexico), and engagement between at least one NT institution and external partners, labeled as NTEX (Northern Triangle + External partners). For each category, we documented the type of activity, sector or topic, and a brief description for each partnership example. Partnership examples were also reviewed and interpreted to reflect one of three approaches from Knight's (2013) FOPA model: functional, organizational and political. While the sources of data were limited, a multi-prong approach was used to make sense of HE regionalization in the NT context.

\section{Findings}

We found 53 examples of collaborative activity that involved higher education institutions (HEIs) from at least one country in the Northern Triangle (NT). In Table 3, we highlight these activities in three distinct categories: The NTCLAB group, NTCAM and NTEX.

Table 3: Types of HE partnerships with institutions from NT countries

\begin{tabular}{|l|l|}
\hline Category & \% Activities \\
\hline Collaboration between 2-3 NT countries (NTCLAB) & 8 out of 53-15\% \\
$\begin{array}{l}\text { Collaboration between 1 NT country and 1 Central American } \\
\text { country/Mexico/Dominican Republic (NTCAM) }\end{array}$ & 15 out of 53-28\% \\
$\begin{array}{l}\text { Collaboration between 1 NT country and an external partner } \\
\text { from outside the region (NTEX) }\end{array}$ & 30 out of 53-57\% \\
\hline
\end{tabular}

Our findings included eight NTCLAB activities, half of which were student or faculty exchanges programs between NT HEIs. These examples would fit in Knight's (2013) model under the functional approach as collaborative academic programs. The other half consisted of agreements or meetings aimed at improving regional coordination between HEIs in the NT. These examples would fit under the political approach of Knight's (2013) model. Partnership activities exclusively between NT HEIs only represented 15 percent of our overall findings.

The NTCAM category highlights 15 examples of collaborations between at least one NT country and a country in Central America (including Mexico), which comprised 28 percent of our overall total of activities. The partnerships included a variety of activities such as student exchanges, research collaborations, conferences and trainings. An examination of these activities with Knight's FOPA model found eight of the partnership activities to fit under the functional approach with collaborations that emphasized collaboration agreements, partnerships, coordination of programs, research initiatives and scholarships. Six examples of partnership activities fit the political approach including the implementation of conferences on literacy, entrepreneurship, internationalization of higher education, food security and nutrition; and a forum/debate on the Plan of Alliance for the Prosperity of the Northern Triangle (A4P). We determined one activity to fit the organizational approach, a cooperation agreement between the National Secretariat for the Science and Technology (SENACYT), Guatemala's University of San Carlos (USAC) and the 
Central American University Council (CSUCA) to create region-wide systemic coordination on science and technology research.

Engaged regional partners in this category included CSUCA, SENACYT, and the Central American Integration System (SICA), along with partner HEIs from Costa Rica, Nicaragua, Mexico and Panama. Key funders for partnership activities in this category include SICA, the United States Agency for International Development (USAID), and the Ford Foundation.

In the NTEX category, examples that involve a country or organization from outside of Central America/Mexico, represented more than half -57 percent - of the total data. Overall, this group yielded 30 examples of activities that contributed to HE regionalization in the NT region. The majority of examples (18) fit under the political category with an emphasis on forums or meetings for higher education partnership in the region and announcements of agreements highlighting plans for collaboration. For example, El Salvador's Central American University (UCA) announced a plan collaboration for student mobility wide range of partners including Fulbright, Canada's Emerging Leaders in the Americas program and Germany's DAAD program. There were 11 examples of activities that fit Knight's (2013) functional description with an emphasis on student mobility or research exchanges. There was one qualification framework example supported by Spain and ERASMUS+ to support curriculum harmonization in Central America. NTEX included one organizational example, a 'Sustainable Economy Observatory' founded by Del Valle University and USAID. This activity could have also been labeled a functional example, which highlights the similarities between approaches cautioned by Knight (2013) in her pilot of the FOPA model.

\section{Discussion}

The findings illustrate that higher education (HE) regionalization in the Northern Triangle (NT) region of Central America is predominantly driven by external partners from the US and the European Union (EU). The investment of the latter's higher education community in the wider Latin America and Caribbean region is evident with the array of support for exchanges, meetings and agreements for future collaborative efforts that involve the EU. The support of external partners was also evident in examples from the NT-Central America, Dominican Republic and Mexico (NTCAM) category.

Knight's (2013) FOPA model helped to make sense of priorities for HE regional engagement, which largely centered on increasing student and faculty mobility, whether between NT countries, the greater Central America or with EU partners. US' role showed firm support for building capacity of HEIs in the region to support economic empowerment and security. In applying Knight's (2013) regionalization continuum from Table 1, HE engagement appeared to revolve largely around the cooperation/collaboration stage with a nudging towards more coordination. There are institutions with the greater Central America to facilitate regionalization (ACAP, AUPRICA, CSUCA and SICA), but HEIs within the NT region are still in the early stages of maximizing opportunities.

While the study offers a roadmap for creating a snapshot of HE contexts with nascent aspirations for developing a higher education area, the analysis approach limited our findings and thus, potential impact of the study. Several of the collaboration examples analyzed in this study require more in-depth investigation of context affecting the level of regional activity between HEIs within the NT region and the greater Central America. Additional time is needed to gather corresponding documents and to gather the perspective of institutional leaders, scholars and regional organizations involved creating greater connectivity between institutions. Additionally, a follow up study on the impact of the Tuning Academy projects in Central America is necessary to help piece together the puzzle of HE regionalization for the NT area. This paper is the beginning of a much needed, prolong study. 


\section{Conclusion}

While Knight's (2013) model was helpful in making sense of existing and potential HE regionalization in the Northern Triangle (NT), our experience with Knight's frameworks suggest that the work is muddled by the interchangeably of terms. For example, the emphasis on student and faculty mobility among higher educations (HEIs) represented both levels of collaboration and coordination. In some cases, it may have also reflected a great deal more integration, but we needed additional data to ascertain this point. Knight (2013) does reflect on the interchangeability of terms in her framework, which is not necessarily a detriment for application, but more of a illustration of the complexity involved with understanding HE regionalization more concretely.

What we learned is that the current landscape for regionalization remains driven by a North-South dynamic, but the conditions exist for increase collaborations driven by South-South engagement. Within the NT region, additional perspective is needed to understand more accurately the challenges and opportunities for regionalization. Moreover, future studies will inform of how post-conflict, emerging societies can build HE regional areas that eventually become independent of Northern influence.

\section{References}

ACAP. 2019. "Inicio." Agencia Centroamericana de Acreditación de Postgrado. Retrieved from http://www.acapca.com/.

Albo, Marco Velazquez. 2017. "Tuning History in Latin America." Arts \& Humanities in Higher Education, 16(4), 358-370. https://doi:10.1177/1474022216686522.

AUPRICA. 2019. "Inicio." Asociación de Universidades Privadas de Centroamérica y Panamá. Retrieved from http://www.auprica.com/wp/.

Azevedo, Mário L.N. 2014. "The Bologna Process and Higher Education in Mercosur: Regionalization or Europeanization?" International Journal of Lifelong Education, 33(3): 411-427, https://doi: 10.1080/02601370.2014.891884.

Carducci, Michele and Lidia P. Castillo Amaya. 2012. "Comparative Regionalism and Constitutional Imitations in the Integration Process of Central America.” Eunomia. Rivista semestrale del Corso di Laurea in Scienze Politiche e delle Relazioni Internazionali Eunomia, 2: 7-28. https://doi:10.1285/i22808949a1n2p7.

Casalet R., Mónica, and Edgar M. Buenrostro. 2014. "La Integración Regional Centroamericana en Ciencia, Tecnología e Innovación: Un Nuevo Desafío." Economía: Teoría y Práctica 40: 165-193. Retrieved from http://www.scielo.org.mx/pdf/etp/n40/n40a7.pdf

Chao, Roger Y. 2014. "Pathways to an East Asian Higher Education Area: A Comparative Analysis of East Asian and European Regionalization Processes." Higher Education, 68(4): 559-575. https://doi.org/10.1007/s10734-0149728-y.

Choi, Edward W. 2017. "Higher Education Regionalization in East Asia." International Higher Education, no. 90: 2628. https://doi.org/10.6017/ihe.2017.90.10008.

Colburn, Forrest D. and Arturo S. Cruz. 2016. "Trouble in the "Northern Triangle". Journal of Democracy 27(2): 7985. https://doi.org/10.1353/jod.2016.0024.

Congressional Research Service. 2019. Central American Migration: Root Causes and U.S. Policy. Retrieved from https://crsreports.congress.gov/product/pdf/IF/IF11151

CSUCA. 2019. "Confederación Universitaria Centroamericana”. Consejo Superior Universitario Centroamericano. Retrieved from http://www.csuca.org. 
Eta, Elizabeth A. 2015. "Policy Borrowing and Transfer, and Policy Convergence: Justifications for the Adoption of the Bologna Process in the CEMAC Region and the Cameroonian Higher Education System through the LMD Reform". Comparative Education, 51(2): 161-178, https://doi:10.1080/03050068.2014.941174.

Eta, Elizabeth Agbor, Johanna Kallo and Risto Rinne. 2018. "Process of Transfer and Reception of Bologna Process Ideas in the Cameroon Higher Education System." European Educational Research Journal, 17(5): 656-675. https://doi: 10.1177/1474904117733376.

Felsen, David. March/April 2016. "Higher Education Cooperation with Latin America." International Educator, 25(2): 52-55. Retrieved from https://www.nafsa.org/sites/default/files/ektron/files/underscore/ie marapr16 forum.pdf.

Ferreyra, María M., Ciro Avitabile, Javier B. Álvarez, Francisco P. Haimovich and Sergio Urzúa. 2017. At a Crossroads: Higher Education in Latin America and the Caribbean (English). Washington, D.C.: World Bank Group, 2017.

Inter-American Development Bank. 2014. Plan of the Alliance for Prosperity in the Northern Triangle: A Road Map prepared by the countries of the northern triangle. Retrieved from http://idbdocs.iadb.org/wsdocs/getdocument.aspx?docnum=39224238

Irazabal, Clara, Carmen Mendoza-Arroyo, Catalina Ortiz Arciniegas, Rubyselen Ortiz Sanchez and Jairo Maya. 2015. "Enabling Community-Higher Education Partnerships: Common Challenges, Multiple Perspectives." Current Opinion in Environmental Sustainability, 17: 22-29. https://doi.org/10.1016/j.cosust.2015.07.020.

Kim, Inhwa and Jasna Kuljis. 2010. "Applying Content Analysis to Web-Based Content". Journal of Computing and Information Technology, 18(4): 369-375. https://doi.org/10.2498/cit.1001924.

Koehn, Peter H. 2012. "Turbulence and Bifurcation in North-South Higher-Education Partnerships for Research and Sustainable Development." Public Organization Review, 12(4): 331-355. https://doi.org/10.1007/s11115-0120176-9.

Knight, Jane. 2013. "A Model for the Regionalization of Higher Education: The Role and Contribution of Tuning". Tuning Journal for Higher Education, 1(1): 105-125. https://doi.org/10.18543/tjhe-1(1)-2013pp105-125.

Meyer, Peter J., and Clare R. Seelke. 2011. Central America Regional Security Initiative: Background and Policy Issues for Congress. Washington, DC: Congressional Research Service, Library of Congress.

Muñoz V., Luis. 2008. "Integración Regional Centroamericana de la Educación Superior Pública: Escenarios y Desafíos. Revista Electrónica Actualidades Investigativas en Educación 8(no.3) Retrieved from http://www.redalyc.org/articulo.oa?id=44713048012 .

Saldaña, Johnny. 2013. The Coding Manual for Qualitative Researchers. London: Sage.

SICA. 2019. "SICA en breve." Sistema de la Integracion Centroamericana. Retrieved from https://www.sica.int/sica/sica_breve.aspx.

Soto, A. Willy and Max Sánchez Ulloa. 2014. Centroamérica: Casa Común e Integración Regional. Costa Rica: Universidad Nacional de Costa Rica - CSUCA.

Swallow, John R. 1975. "Regional Cooperation: The Permanent Secretariat of the Central American Higher Education Confederation: CSUCA." ProQuest Dissertations Publishing. Retrieved from http://search.proquest.com/docview/302762805/.

Svenson, Nanette. 2015. "Central American Outliers: Leveraging International Cooperation for Research Productivity." In Private Universities in Latin America: Research and Innovation in the Knowledge Economy, edited by Gregorutti, Gustavo and Jorge Enrique Delgado, 157-183, New York: Palgrave Macmillan.

Svenson, Nanette. 2018. "INCAE, Harvard, and International Development: Research for Progress in Central America." In North-South University Research Partnerships in Latin America and the Caribbean, edited by Gregorutti, Gustavo and Nanette Svenson, 61-85, New York: Palgrave Macmillan. 
Tuning Academy. 2019. "Projects." University of Deusto/University of Groningen. Retrieved from http://tuningacademy.org/projects.

UNDP. 2019. Human Development Report 2019, Beyond Income, Beyond Averages, Beyond Today: Inequalities in Human Development in the $21^{\text {st }}$ Century. New York, NY: United Nations Development Program Publications. Retrieved from http://hdr.undp.org/sites/default/files/hdr2019.pdf.

United Nations. 2019. Sustainable Development Goals. Retrieved from https://sustainabledevelopment.un.org/?menu=1300.

U.S. Department of State. 2018. "U.S. Strategy for Central America." United States Department of State. Retrieved from https://www.state.gov/p/wha/rt/strat/index.htm.

Verger, Antoni and Javier Pablo Hermo. 2010. "The Governance of Higher Education Regionalization: Comparative Analysis of the Bologna Process and MERCOSUR-Educativo." Globalisation, Societies and Education, 8(1): 105-120. https://doi-org.proxyau.wrlc.org/10.1080/14767720903574116. 